\title{
Integrated analysis of long non-coding RNA and mRNA expression in endometrial stromal cells induced by poly (I:C) identifies immune response genes
}

\section{Ming Zhang ( $\nabla$ zhm3000@163.com )}

Sichuan Agricultural University https://orcid.org/0000-0003-2728-128X

Yan Zhang

Sichuan agricultural University

Qiuying Wu

Sichuan Agricultural University

Ling Xu

Sichun Agricultural University

\section{Yutian Zeng}

Sichuan Agricultural University

Chuanzhi Lu

Sichuan Agricultural University

\section{Yan Ren}

Sichuan Agricultural University

\section{Zhicheng Wang}

Sichusn Agricultural University

\section{Guangbin Zhou}

Sichusn Agricultural University

\section{Changjun Zeng}

Sichuan Agricultural University

\section{Zhicai Zuo}

Sichuan Agricultural University

\section{Tianzeng Song}

Sichuan Agricultural University

\section{Research article}

Keywords: immune response, endometrial stromal cells, long noncoding RNA, poly $(\mathrm{I}: \mathrm{C})$

Posted Date: February 11th, 2020 
DOI: https://doi.org/10.21203/rs.2.23076/v1

License: (c) (1) This work is licensed under a Creative Commons Attribution 4.0 International License. Read Full License 


\section{Abstract}

Background The uterus of an animal is relatively easily infected by pathogenic microorganisms, which can cause serious reproductive disorders and economic loss to animal husbandry. The presence of long noncoding RNA (IncRNA) is closely related to many diseases. Poly $(\mathrm{l}: \mathrm{C})$ is a synthetic double-stranded RNA that is often used as a substitute for dsRNA viral infection. In this study, we analyzed the mRNA and IncRNA expression profiles of in vitro cultured rabbit endometrial stromal cells (ESCs) after poly(I:C)induction, to explore the role of these RNAs in the immune response.

Results We identified 10,927 IncRNAs and 20,494 mRNAs, of which 291 IncRNAs and 1311 mRNAs were significantly differentially expressed (DE) between the control and poly $(\mathrm{l}: C)$ groups $(p<0.05)$. $G 0$ and KEGG analysis showed that DE genes and target genes of DE IncRNAs were enriched in relation to the occurrence of various diseases, development of tissues and organs, metabolic processes, and the immune response. Moreover, these genes were also enriched in many pathways related to immune and inflammatory responses, such as the toll-like receptor and the NF-KB and Jak-STAT signaling pathways. Co-expression analysis of IncRNA and mRNA revealed that there were significant relationships between a number of IncRNAs including MSTRG.153189.1, MSTRG.102664.8, MSTRG.39626.1, MSTRG.68469.1, MSTRG.137189.4, MSTRG.32118.5 and MSTRG.76080.1, and the immune system genes, CCL2, CCL5, IL1, IL-6, IFN and ISG15, which suggested that IncRNAs in ESCs might be involved in regulation of the immune response to poly $(\mathrm{l}: \mathrm{C})$ through genes related to immune signaling pathways.

Conclusions Our results provide both transcriptomic and epigenetic insights into the immune response of uterine cells to dsRNA virus infection. Comprehensive IncRNA and mRNA transcriptomes in rabbit ESCs exposed to poly(l:C) were profiled. Co-expression analysis identified an integrated IncRNA-mRNA interaction network, implying that key genes or IncRNAs exerted critical influences on the immune response to virus infection.

\section{Introduction}

As the most important part of the reproductive system, the uterus plays a vital role in animal husbandry. Although the endometrial lining of the uterus has a built-in defense mechanism to deal with microbial invasion, the organ is still very vulnerable to pathogens that can cause serious reproductive disorders. In addition to bacteria, viruses constitute a major threat to the reproductive system and the overall health of an animal. In vivo and in vitro studies have shown that intrauterine viral infection can cause not only metritis and endometritis, but also infertility, miscarriage, premature birth, and death of mothers and babies. Viral infections with pathogens such as herpes virus[1-3], Zika virus (ZIKV)[4], hepatitis E virus (HEV) $[5,6]$, and bovine viral diarrhea virus (BVDV) $[7,8]$ result in huge economic losses for livestock raisers, dairymen and ranchers. Therefore, it is very important to study the mechanism of the immune and inflammatory response to viral infection in utero or in vitro with cultured uterine cells. 
Long non-coding RNAs (IncRNAs) are transcripts longer than 200 nucleotides with little or no identifiable protein-coding potential $[9,10]$. Recent studies have shown that the expression level of IncRNAs changed in response to virus infection, and the expression characteristics of IncRNAs were closely related to disease development. For example, infection with porcine reproductive and respiratory syndrome virus (PRRSV) caused changes to a large number of mRNAs and IncRNAs in porcine alveolar macrophages (PAMs), including a significant down-regulation of genes involved in IFN-related signaling pathways, proinflammatory cytokines and chemokines, phagocytosis, and antigen processing and presentation, indicating aberrant functioning of PAMs [11]. Recent evidence indicates that IncRNAs regulate gene transcription and translation, and can change the characteristics of related proteins by interacting with DNA, RNA or protein molecules [12-14]. For example, IncRNA\#32 binds to activating transcription factor 2 (ATF2) and positively regulates the host antiviral response, thus inhibiting EMCV replication and hepatitis virus infection [15]. However, IncRNA NRAV acts as a negative regulator of the antiviral response by inhibiting transcription of multiple ISGs [16]. In vivo, silencing of IncRNA-ACOD1 significantly attenuated viral infection through IFN/IRF3-independent pathways. Cytoplasmic IncRNA-ACOD1 directly bound to the metabolic enzyme, glutamic-oxaloacetic transaminase (GOT2), near the substrate niche, enhancing its catalytic activity and promoting viral replication [17]. These findings implied that the differential expression of IncRNAs and mRNAs played an important part in viral infection and in regulating the host response.

Double-stranded RNA (dsRNA) viruses comprise a large group of RNA viruses with a wide range of hosts, ranging from bacteria, fungi, and protozoa to higher animals and plants. Poly $(I: C)$ is a synthetic dsRNA that is often used as a stand-in for RNA virus infection in studies of pathogenesis[18]. After exposure to poly(l:C), TLR3 recruits a unique connector molecule with a TIR domain-containing adaptor inducing interferon- $\beta$ (TRIF) via its own toll/interleukin-1 receptor domain (TIR) [19]. This involves the recruitment of TNF receptor-associated factor 6 (TRAF6) or receptor-interacting protein 1 (RIP1), TAK1 and IKK, followed by activation of the transcription factors, NF-KB and AP-1, which promote expression of inflammatory factors and chemokines such as TNF-a, IL-6 and CXCL10 [20]. TRIF induces the expression of type I IFN and related genes by recruiting TRAF3 to activate IRF3 and IRF7 [21, 22]. TLR3-deficient mice showed significantly attenuated poly(I:C)-induced production of type I IFNs and inflammatory cytokines, and significantly resisted poly(I:C)-induced death [23, 24]. In addition, retinoic acid-inducible gene 1 (RIG1 ) and melanoma differentiation-associated gene-5 (MDA5) also specifically recognized poly(l:C) $[25,26]$.

RNA-seq technology has been widely used in transcriptome research, for determining the global expression profiles of mRNA or IncRNA in cultured cells or animals after induction [27-29]. The objective of this study was to assess the global expression profiles of IncRNA and mRNA in endometrial stromal cells (ESCs) of rabbits after simulated dsRNA virus infection with poly(I:C), and to understand how the interaction of IncRNA-mRNA influences the uterine immune response.

\section{Results}

\section{Overview of RNA sequencing}


After quality control, we obtained a total of $100.94 \mathrm{~Gb}$ of clean sequencing data. The clean data from each sample averaged $16.06 \mathrm{~Gb}$, and the Q30 base percentage was not less than $92.40 \%$. The mapping rate of each sample to the Oryctolagus cuniculus reference genome: OryCun2.0 (https://www.ncbi.nlm.nih.gov/assembly/GCF_000003625.3) ranged from 89.33-90.47\% (Table 1).

Table 1

Summary of quality control and mapping for each sample.

\begin{tabular}{|c|c|c|c|c|c|c|}
\hline $\begin{array}{l}\text { Sample } \\
\text { name }\end{array}$ & C1 & $\mathrm{C} 2$ & C3 & $\mathrm{P} 1$ & $\mathrm{P} 2$ & P3 \\
\hline Clean reads & 112594520 & 117210132 & 107419948 & 114902272 & 113400908 & 109847732 \\
\hline Clean bases & $16.82 G$ & $17.53 G$ & $16.06 \mathrm{G}$ & $17.17 \mathrm{G}$ & $16.96 \mathrm{G}$ & $16.40 \mathrm{G}$ \\
\hline $\begin{array}{l}\text { GC } \\
\text { content(\%) }\end{array}$ & 54.68 & 53.92 & 53.39 & 53.88 & 53.44 & 53.05 \\
\hline Q30(\%) & 93 & 93.69 & 92.6 & 92.4 & 92.45 & 93.1 \\
\hline $\begin{array}{l}\text { Mapped } \\
\text { Reads }\end{array}$ & $\begin{array}{l}100583279 \\
(89.33 \%)\end{array}$ & $\begin{array}{l}105509450 \\
(90.02 \%)\end{array}$ & $\begin{array}{l}96423061 \\
(89.76 \%)\end{array}$ & $\begin{array}{l}103822985 \\
(90.36 \%)\end{array}$ & $\begin{array}{l}102171743 \\
(90.10 \%)\end{array}$ & $\begin{array}{l}99376004 \\
(90.47 \%)\end{array}$ \\
\hline
\end{tabular}

We discovered 20,494 genes, including 4138 new genes (Table S1). A total of 10,927 IncRNAs were also identified using the CNCl, CPAT, CPC and PFAM software (Table S2), including 6029 IncRNAs, 1753 antisense IncRNAs, 2307 intronic IncRNAs, and 838 sense IncRNAs (Fig. 1). In addition, we compared length, exon number, and open reading frame (ORF) length in mRNAs and IncRNAs. As shown in Fig. 2, the average length and ORF length of mRNAs were significantly greater than for IncRNAs. The average number of exons in the mRNAs was larger than that in the IncRNAs, and the mRNAs contained a wider range of exons from one to thirty, whereas many IncRNAs had only two or three exons.

\section{Differential expression analysis of mRNA and IncRNA}

With fold-change $\geq 2.0$ and FDR $<0.05$ as the screening criteria, we found a total of 1311 mRNAs that were differentially expressed between the control group and the poly $(\mathrm{I}: \mathrm{C})$ group, including 1043 upregulated mRNAs and 268 down-regulated mRNAs (Table S3). Among the IncRNAs, 291 were differentially expressed-233 up-regulated and 58 down-regulated (Table S4). The volcano plot showed DE IncRNAs and mRNAs (Fig. 3).

\section{GO and KEGG enrichment analysis of DE genes}

The identified DE genes were significantly enriched into $132 \mathrm{GO}$ items $(p<0.05)$ (Fig. 4A). In biological processes, the most significantly enriched items included protein autophosphorylation (G0:0046777), 
peptidyl-tyrosine phosphorylation (G0:0018108), regulation of MAPK cascade (G0:0043408), transmembrane receptor protein tyrosine kinase signaling pathway (G0:0007169) and inactivation of MAPKK activity (GO:0051389). In addition, the immune response, interferon-gamma response and regulation of JNK cascade were also significantly enriched in GO. With regard to cellular components, the top five items were plasma membranes (GO: 0005886), receptor complexes (GO: 0043235), cellular parts (GO: 0044464), cytosolic parts (G0:0044445) and the COP9 signalosome (GO:0008180). For molecular function, the top five items included insulin-like growth factor binding (GO: 0005520), transmembrane receptor protein tyrosine kinase activity (G0:0004714), nucleotide binding (GO: 0000166), protein tyrosine kinase activity (G0:0004713) and insulin-like growth factor I binding (G0:0031994) (Table S5).

To further elucidate the function of the differentially expressed genes, we performed KEGG pathway analysis. A total of $258 \mathrm{KEGG}$ pathways were enriched, of which 31 pathways were significantly enriched $(p<0.05)$, such as the toll-like receptor signaling pathway (ko04620), the NF-KB signaling pathway (ko04064), TNF signaling pathway (ko04668), RIG-Ilike receptor signaling pathway (ko04622), NOD-like receptor signaling pathway (ko04621), cytokine-cytokine receptor interaction (ko04060), and the chemokine signaling pathway (ko04062) (Table S6). Figure 5A shows the top twenty significantly enriched KEGG pathways for DE mRNAs.

\section{Target genes and functional analysis of DE IncRNAs}

We attempted to identify the targets of the DE IncRNAs and to determine their function. The results showed that there were 26 cis-target genes in 27 IncRNAs and 1297 trans-target genes in 291 IncRNAs (Table S7). GO enrichment analysis showed that the target genes of DE IncRNAs were enriched in 2727 GO items, and significantly enriched in $124 \mathrm{GO}$ items $(p<0.05)$, involving processes such as immune responses (GO:0002285; G0:0002822), regulation of the MAPK cascade (G0:0043408), regulation of the JNK cascade (G0:0046328), signal transduction (G0:0007165), and negative regulation of cell death (G0:0060548) (Fig. 4B) (Table S8). In addition, KEGG analysis showed that 299 KEGG pathways were enriched, and nine pathways were significantly enriched: response to HTLV-I infection (ko05166), glycosaminoglycan biosynthesis-chondroitin sulfate/dermatan sulfate (ko00532), endocytosis (ko04144), endocrine resistance (ko01522), Huntington's disease (ko05016), response to salmonella infection (ko05132), N-glycan biosynthesis (ko00510), the TNF signaling pathway (ko04668), and viral carcinogenesis (ko05203) (Table S9). Figure 5B gives the top twenty enriched KEGG pathways for the target genes of DE IncRNAs.

\section{LncRNA-mRNA network analysis}

We selected seven IncRNAs and their target genes to construct a co-expression network to identify the interaction between DE IncRNA and mRNA (Fig. 6). Among the enriched signaling pathways, we selected relevant genes and IncRNAs in viral infection pathways such as RIG-1, toll-like receptor, NOD-like receptor, PI3K-Akt, MAPK, NF-KB, and Jak-STAT. Interestingly, these seven IncRNAs regulate many immune-related factors, such as pro-inflammatory cytokines (TNF-a/IL-1/IL-6), chemokines (CCL5/CXCL8), interferons $(\mathrm{IFN}-\alpha / \beta)$ and interferon-stimulated genes (ISG15). 


\section{qRT-PCR validation of IncRNA and mRNA related to the immune response}

The expression levels of seven candidate IncRNAs and their twelve targeted DE genes were determined by qRT-PCR (Fig. 7). The results were consistent with the RNA-seq data, which suggested that poly(l:C) induced the co-expression network through the interaction between DE IncRNAs and mRNAs in ESCs, and that the RNA-seq data were reliable.

\section{Discussion}

Intrauterine virus infection has caused significant economic loss for those engaged in animal husbandry. Double-stranded viral RNA is produced in the life cycle of most viruses and serves as a PAMP in the viral recognition pathway. Virus infection is a complex biological process that is regulated by coordinated genes, including coding genes and non-coding RNA. Although some IncRNAs and mRNAs have been proven to play a role in viral infection, there has been no comprehensive investigation. In this study, rabbits were selected as experimental models and poly $(\mathrm{l}: \mathrm{C})$ was used as the virus mimic. RNA-seq technology was used for the first time to comprehensively and systematically analyze IncRNAs and mRNAs in poly(l:C)-treated ESCs.

We detected 20,494 mRNAs and 10,927 IncRNAs in ESCs of rabbits. Among them, we found that many genes were involved in the development and regulation of uterine function, such as PTGS2, TGF $\beta 1$, RDH10, SLC5A1, SMAD2, GDF9, FSH 3 . Retinol dehydrogenase 10 (RDH10) is a key enzyme for vitamin A metabolism and is essential for embryonic patterning, morphogenesis and survival [30]. In addition, TGF$\beta 1$ (transforming growth factor-beta 1 ) is abundantly expressed in the endometrium and secreted into the uterine fluid to regulate uterine function [31]. Growth and differentiation factor 9 (GDF9) is secreted by oocytes and plays a leading role in the control of ovarian function in reproduction [32]. The IncRNA, MSTRG.259847.2, cis-regulates its target gene, SMAD2, which is an important regulator of pituitary function and reproduction that interacts with GDF9 and FSH $\beta$ to affect FSH synthesis [33]. We also identified new mRNAs and new IncRNAs in large numbers, which may provide insights into their function during viral infection. We also found 1311 DE mRNAs and 291 DE IncRNAs before and after poly(l:C) induction, and the number of up-regulated genes was much larger than the number of down-regulated genes, indicating that more mRNAs and IncRNAs were activated after infection.

LncRNA not only regulates the expression of adjacent protein-coding genes by cis-regulation [34, 35], but also the expression of genes on other chromosomes by trans-regulation [36, 37]. Our results showed 26 cis- and 1297 trans-regulatory sites. The DE regulatory IncRNAs produced by virus invasion, the host cell antiviral immune response, and by apoptosis could be useful as disease biomarkers or as potential therapeutic targets [38]. Compared with the control group, we found that MSTRG.92782.1 (log2FC = 12.37) and MSTRG.101521.9 (log2FC = -10.26) were the most significantly up-regulated and downregulated IncRNAs after poly $(\mathrm{I}: \mathrm{C})$ treatment. A total of 671 target genes of MSTRG.92782.1 were found and all of them were trans-regulated, five trans-regulated target genes of MSTRG.101521.9 were also 
identified, which may have functions in the infection process. Prostaglandins (PGs) are involved in reproductive processes, such as ovulation, fertilization, embryo development and early implantation [39]. PTGS2 is a rate-limiting enzyme in prostaglandin synthesis and a key enzyme regulating PG synthesis during corpus luteum dissolution and embryo implantation [40]. In our results, PTGS2 expression was significantly up-regulated by 62 different IncRNAs, indicating that IncRNAs may regulate the endometrial secretory function by promoting prostaglandin production after exposure to poly $(\mathrm{I}: \mathrm{C})$.

We also performed functional analysis of DE mRNAs and IncRNAs. GO analysis showed that the target genes were involved in many biological processes, such as the development of various tissues and organs, regulation of the MAPK cascade, regulation of the JNK cascade, the immune response, signal transduction and metabolism. KEGG pathway analysis showed that differential target genes of IncRNAs were significantly enriched in the TNF signaling pathway, the toll-like receptor signaling pathway, the NOD-like receptor signaling pathway, and the NF-KB signaling pathway. In this study, the cis- and transtargeted genes of seven DE IncRNAs were used to predict their potential roles in the regulation of the immune response triggered by poly $(I: C)$. Combined with $D E$ genes related to viral infection, we constructed an interaction network involving seven DE IncRNAs and 78 trans-target genes, mainly involving PI3K-Akt, toll-like receptors, RIG-I-like receptor, NOD-like receptor, MAPK, NF-KB, and the JakSTAT signaling pathway. This revealed the potential function of DE-IncRNAs and mRNAs in viral regulation and the host's immune response.

We next explored the role of these seven IncRNAs and their corresponding target genes in uterine infection and the immune response. Viral proliferation in cells triggers immediate (innate) and delayed (adaptive) immune responses [41, 42]. In this study, many proven immune genes were identified, such as the cytokines, IL-1 $\beta$ and IL-6, and the chemokines, CCL5 and CCL2 [43]. The seven verified IncRNAs targeted several different cytokines and chemokines that promoted or inhibited the antiviral response. Continued expression of these molecules could lead to pathological effects $[44,45]$ as their expression pattern changed in response to infection. Cytokines mainly regulate the inflammatory response and increase the adhesion of neutrophils to vascular endothelium, resulting in an influx of polymorphonuclear (PMN) cells and macrophages into the uterus [46]. The delicate balance between pro-inflammatory cytokines and anti-inflammatory cytokines plays a key role in pathogen clearance [47, 48]; however, we did not detect any changes in expression of typical anti-inflammatory cytokines such as IL-4, IL-10 and IL13. There is sufficient evidence to show a significant correlation between pro-inflammatory cytokines and the severity and persistence of uterine infections [49-51]. The body's immune response is maintained in balance, but virus invasion can easily break the balance. We hypothesized that changes in key immunerelated molecules may be responsible for the development of uterine infections. The expressions of IncRNAs are regulated by time, space, developmental stage and multiple genes [52, 53]. This characteristic of IncRNAs coincides with the dynamic changes in the development of the immune system, the rapid response to external antigens or invading pathogens, and the preservation of immune homeostasis. Better control of the inflammatory response may be beneficial for resistance to viral infection, and IncRNA could be a target in this process. 
IFN- $\alpha / \beta$ production after viral infection is one of the main innate responses to the virus and also can enhance the adaptive immune response to the virus. IFN- $\alpha$ and $-\beta$ are pleiotropic cytokines, which can antagonize the virus by inducing the expression of antiviral proteins [54,55], including IFN-stimulated gene 15 (ISG15), 2', 5'-oligoadenylate synthetase 1 (OAS1), and MxGTPase 1 (MX1) as the best characterized examples [56]. These proteins amplify antiviral signals, degrade viral RNA and block viral mRNA transcription respectively [57-59]. Our results showed that poly $(1: C)$ significantly increased these antiviral proteins, which may be related to the host response to viral infection. In our interaction results, MSTRG.102664.8 was significantly up-regulated and its trans-target gene IFN- $\beta$ was also up-regulated, indicating that MSTRG.102664.8 may play a role in the production of downstream antiviral factors through up-regulation of IFN- $\beta$ expression. After poly(l:C) stimulation, ISG15 increased significantly and the corresponding MSTRG.102664.8, MSTRG.137189.4, MSTRG.39626.1, MSTRG.68469.1 increased significantly; but, MSTRG.153189.1 decreased significantly, indicating that ISG15 was regulated by multiple IncRNAs at the same time. LncRNAs play an important regulatory role in the fight between virus and host, involving the transcription of virus and host genes, stability and translation of mRNAs and the antiviral response of the host $[60,61]$.

\section{Conclusions}

In this study, we screened many newly predicted and differentially expressed IncRNAs and mRNAs, and analyzed their functions. Through co-expression network analysis, we identified several hub genes that may play pivotal roles in the inflammatory response to viral infection and found seven DE IncRNAs that were strongly related to these hub protein genes. Moreover, they were also enriched in pathways related to immune and inflammatory responses, such as toll-like receptor signaling pathways, the NF-kB signaling pathway and the Jak-STAT signaling pathway. We expect that the DE mRNAs and IncRNAs identified in this study will provide valuable transcriptomic and epigenetic insights into the mechanism of the innate immune response to dsRNA virus infection.

\section{Materials And Methods}

\section{Culture and treatment of ESCs}

Rabbit ESCs were cultured and treated according to previously published methods from this laboratory (Figure S1). The purified ESCs were stimulated with 0 or $10 \mu \mathrm{g} / \mathrm{ml}$ of poly(l:C) for $6 \mathrm{~h}$. Experiments were repeated three times. The control group samples were named $\mathrm{C} 1, \mathrm{C} 2, \mathrm{C} 3$, and the samples in the poly $(\mathrm{l}: \mathrm{C})$ treatment group were P1, P2, and P3.

\section{Total RNA extraction, library construction, and RNA-seq}

The cells were washed three times with sterile PBS, and total RNA was extracted using Trizol reagent (Invitrogen, Carlsbad, CA, USA). RNA degradation and contamination were monitored on $1.5 \%$ agarose gels. RNA purity and concentration were measured using a NanoDrop 2000 spectrophotometer (Thermo 
Fisher Scientific, Wilmington, DE, USA) and the Agilent Bioanalyzer 2100 system (Agilent Technologies, Santa Clara, CA, USA) was used to detect RNA integrity.

A total of $1.5 \mu \mathrm{g}$ RNA per sample was used as input material for rRNA removal using the Ribo-Zero rRNA removal kit (Epicentre, Madison, WI, USA). Sequencing libraries were generated using the NEBNext ${ }^{\mathrm{R}} \mathrm{Ultra}^{\mathrm{TM}}$ Directional RNA Library Prep Kit for Illumina ${ }^{R}$ (NEB, Ipswich, MA, USA) following manufacturer's recommendations, and index codes were added to attribute sequences to each sample. In order to select insert fragments of preferentially $150-200 \mathrm{bp}$ in length, the library fragments were purified with AMPure XP Beads (Beckman Coulter, Beverly, MA, USA). Then 3 II USER Enzyme (NEB, Ipswich, MA, USA) was added to size-selected, adaptor-ligated CDNA at $37^{\circ} \mathrm{C}$ for $15 \mathrm{~min}$ before PCR. PCR was performed with Phusion High-Fidelity DNA polymerase, universal PCR primers and Index $(X)$ Primer. After amplification, PCR products were purified (AMPure XP system) and library quality was assessed using the Agilent Bioanalyzer 2100 and qPCR. The library preparations were sequenced by Illumina Hiseq 2000 platform.

\section{Quality analysis, mapping, and transcriptome assembly}

Clean data (clean reads) were obtained from raw data by removing reads containing adapters, reads containing poly- $\mathrm{N}$ and low quality reads. All the downstream analyses were based on clean data with high quality. The transcriptome was assembled using the StringTie (v1.3.1) software on the reads mapped to the reference genome. Sequence alignment and subsequent analysis was performed using the designated reference genome of Oryctolagus cuniculus (http//:www.OryCun2.0_NCBI.Oryctolagus_cuniculus.OryCun2.0_NCBI.genome.fa.)Clean reads were mapped to the Oryctolagus cuniculus genome sequence with HISAT2. The mapped reads of each sample were assembled by StringTie [62].

\section{Identification of mRNA and IncRNA}

Based on the selected reference genome sequence, mapped reads were spliced using StringTie (v1.3.1) software, and compared with the original genomic annotation information to find the original unannotated transcribed region and to discover new transcripts and new genes of the species to supplement and improve the original genome annotation information. The sequences in which the encoded peptide chain was too short ( $<50$ amino acids) or contained only a single exon were filtered out.

The assembled transcript was annotated with the gffcompare program to complement and refine the original genomic annotation information. The unknown transcripts were used to screen for putative IncRNAs. Four computational approaches include CPC2/CNCl/ Pfam/CPAT were combined to sort nonprotein coding RNA candidates from putative protein-coding RNAs in the unknown transcripts. Putative protein-coding RNAs were filtered out using a minimum length and exon number threshold. Transcripts longer than $200 \mathrm{nt}$ with more than two exons were selected as IncRNA candidates and further screened using CPC2/CNCI/Pfam/CPAT. The different types of IncRNAs, including lincRNA, intronic IncRNA, antisense IncRNA, and sense IncRNA, were selected using cuffcompare (v2.1.1) software. 


\section{Expression level and difference analysis of mRNA and IncRNA}

StringTie (v1.3.1) was used to calculate FPKMs of both IncRNAs and coding genes in each sample. FPKM (fragments per kilobase of exon per million fragments mapped) was calculated based on the length of the fragments and reads count-mapped to each fragment. Differential expression analysis of two groups was performed using the DESeq R package (v1.10.1). The mRNAs and IncRNAs with fold change $(F C) \geq 2$ and false discovery rate $(F D R)<0.05$ were considered to show significant differential expression.

\section{Prediction of IncRNA target genes}

The adjacent genes in the range of $100 \mathrm{~kb}$ upstream and downstream of IncRNA were used as the cistarget genes. The correlation between IncRNA and mRNA was analyzed by Pearson correlation coefficient method, and the genes with absolute value of correlation $>0.9$ and significant at $p<0.01$ were used as trans-target genes.

\section{GO and KEGG enrichment analysis}

Gene ontology (GO) enrichment analysis of the differentially expressed (DE) genes was implemented by using the top GO R packages and was categorized into biological processes, cellular components, and molecular function. We used KOBAS software to test the statistical enrichment of DE genes in the Kyoto Encyclopedia of Genes and Genomes (KEGG) pathways.

\section{LncRNA-mRNA network analysis}

To understand the relationship between IncRNAs and their related mRNAs, we performed a co-expression analysis on the differentially expressed IncRNAs and mRNAs. The key pathways with significant differences in KEGG pathway were screened out, and CytoScape 3.3.0 was used to visualize the interaction network of IncRNA and mRNA.

\section{qRT-PCR verification}

Reverse transcription reactions of mRNA and IncRNA were performed using the Prime Script ${ }^{\text {TM }}$ RT reagent kit (Takara, Dalian, China) and InRcute IncRNA First-StrandcDNA Synthesis Kit (Tiangen, Beijing, China), respectively, according to the instructions of the kit. SYBR Premix Ex Taq II (Takara, Dalian, China) was used for the expression of mRNA, and InRcute IncRNA qPCR Kit (Tiangen, Beijing, China)was used for the expression of IncRNA, qRT-PCR was performed on a CFX 96 Real-Time PCR Detection System (Bio-Rad, Hercules, CA, USA).The reaction conditions were as follows: pre-denaturated at $95^{\circ} \mathrm{C}$ for $30 \mathrm{~s}$, denaturated at $95^{\circ} \mathrm{C}$ for $30 \mathrm{~s}$, annealed at $60^{\circ} \mathrm{C}$ for $30 \mathrm{~s}$ for 40 cycles. Dissolution curve analysis was performed after amplification: $95^{\circ} \mathrm{C}$ for $10 \mathrm{~s}$, and $65^{\circ} \mathrm{C}$ for $1 \mathrm{~s}$. Thereafter, starting from $65^{\circ} \mathrm{C}$, each cycle temperature was increased by $0.5^{\circ} \mathrm{C}$ for $1 \mathrm{~s}$. Primer information is shown in Table 2 . 
Table 2

Primers of qRT-PCR and product size.

\begin{tabular}{|c|c|c|}
\hline mRNAs and IncRNAs & Primer sequence $\left(5^{\prime}-3^{\prime}\right)$ & Product size (bp) \\
\hline $\mathrm{IL}-1 \beta$ & $\begin{array}{l}\text { F:AAGAAGAACCCGTCCTCTGCAACA } \\
\text { R: TCAGCTCATACGTGCCAGACAACA }\end{array}$ & 97 \\
\hline IL-6 & $\begin{array}{l}\text { F: CTGAAGACGACCACGATCCA } \\
\text { R: AAGGACACCCGCACTCCAT }\end{array}$ & 97 \\
\hline TLR3 & $\begin{array}{l}\text { F: GAACAGAATCAGCAATAGG } \\
\text { R: AGTGAAGTGAGGGACACAC }\end{array}$ & 211 \\
\hline TRIM69 & $\begin{array}{l}\text { F: TCTCCGATGCTGTCCGTTTC } \\
\text { R: GTACGCAGCAATAGCGTCCT }\end{array}$ & 119 \\
\hline IRF7 & $\begin{array}{l}\text { F: TCGACTTCAGCACCTTCTTCCAAG } \\
\text { R: TGACCAGGACCAGGCTCTTGTC }\end{array}$ & 141 \\
\hline OASL & $\begin{array}{l}\text { F: AGCCGACCTATGAAACTGAAGA } \\
\text { R:AGGGCGTATTTGGAGGGTAA }\end{array}$ & 107 \\
\hline OAS2 & $\begin{array}{l}\text { F: GAACCTACTGGTGACGTGGG } \\
\text { R: GGGTGCTCTGTGGCTGTATT }\end{array}$ & 199 \\
\hline TNF & $\begin{array}{l}\text { F: CTCCTACCCGAACAAGGTCA } \\
\text { R: CGGTCACCCTTCTCCAACT }\end{array}$ & 138 \\
\hline CCL5 & $\begin{array}{l}\text { F: CCTCGCCGTCCTCCTCACC } \\
\text { R: GCGGGAGATGTAGGCAAAGCAG }\end{array}$ & 100 \\
\hline CCL17 & $\begin{array}{l}\text { F: GCTGGTGTCGTGGCTTGTAACC } \\
\text { R: GTCTTGGCAGGCGTCTGATGG }\end{array}$ & 95 \\
\hline CXCL16 & $\begin{array}{l}\text { F: GCAGCCGCCACCACTTTCG } \\
\text { R: ACCCACGCACTCCCACACG }\end{array}$ & 141 \\
\hline ISG20 & $\begin{array}{l}\text { F: ACCTAAGAGGGCTGGGACAT } \\
\text { R: TGCCATGAGCTTTGGTGACT }\end{array}$ & 105 \\
\hline MSTRG.153189.1 & $\begin{array}{l}\text { F: GACTCCCCAGGCTACAAACTT } \\
\text { R: GCACCACAGAGGAACAAGAC }\end{array}$ & 100 \\
\hline MSTRG.102664.8 & $\begin{array}{l}\text { F: ATTAGGTACTTGCAGGGCCA } \\
\text { R: CCACGTTTGTCCAAGAGCAG }\end{array}$ & 117 \\
\hline MSTRG.39626.1 & $\begin{array}{l}\text { F: ACGTGTGTAGCAGGAGCATC } \\
\text { R: GCGTAGAGACTGGTCCACAA }\end{array}$ & 171 \\
\hline MSTRG.68469.1 & $\begin{array}{l}\text { F: AAGACGAGTGTGCTCTGCAA } \\
\text { R: TGGCTCAGCAGAAATGGTATGT }\end{array}$ & 155 \\
\hline MSTRG.137189.4 & $\begin{array}{l}\text { F: CACACAGGAGCGAGAGAGTC } \\
\text { R: AACCGTGTCGCACTTGAAGA }\end{array}$ & 154 \\
\hline
\end{tabular}




\begin{tabular}{|lll|}
\hline mRNAs and IncRNAs & Primer sequence (5'-3') & Product size (bp) \\
\hline MSTRG.32118.5 & $\begin{array}{l}\text { F: CTGCCCTTGCGTTCATCCAT } \\
\text { R: TGATGGCCTGGAGGTGAGTT }\end{array}$ & 117 \\
\hline MSTRG.76080.1 & $\begin{array}{l}\text { F: TCCATCCCAGCCTCCTACAA } \\
\text { R: ACAGTTGCAGGCTCAGGTTT }\end{array}$ & 246 \\
\hline
\end{tabular}

\section{Statistical analysis}

All data were expressed as the means \pm standard error of the mean (SEM). The statistical differences were analyzed using the SPSS ( 220.0 , IBM, Chicago, IL, USA) by independent-samples $t$ test. $p<0.05$ was considered statistically significant.

\section{Abbreviations}

ESCs

endometrial stromal cells;ZIKV:Zika virus; HEV:hepatitis E virus; BVDV:bovine viral diarrhea virus; PRRSV:porcine reproductive and respiratory syndrome virus; PAMs:porcine alveolar macrophages; GOT2:glutamic-oxaloacetic transaminase; dsRNA:double-stranded RNAITRAF6:TNF receptor-associated factor 6[RIP1:receptor-interacting protein 1; G0:gene ontology; KEGG:Kyoto Encyclopedia of Genes and Genomes; RDH10:retinol dehydrogenase 10; TGF- $\beta 1$ :transforming growth factor beta 1; GDF9:growth and differentiation factor 9; PGs:prostaglandins; ISG15:IFN-stimulated gene 15; OAS1:2', 5'-oligoadenylate synthetase 1; MX1:MxGTPase 1.

\section{Declarations}

\section{Acknowledgements}

We thank Biomarker Technologies Corporation (Beijing, China) for RNA-sequencing, and thank Tang Qianzi (Institute of Animal Genetic and Breeding, Sichuan Agricultural University) for helping with data analysis.

\section{Funding}

The study was supported by the Fund for International Exchange, through cooperation with Sichuan Province (GH2020), and by funding from the Provincial Science and Technology Department (JY20140227).

\section{Author's contributions}


MZ conceived the study and designed the project. YZ performed bioinformatics analyses and drafted the manuscript. YZ, QYW and LX conducted the $\mathrm{QPCR}$ assay. CZL and ZCW assisted with sample collection. YTZ and YR revised the manuscript. GBZ, CJZ, ZCZ, and TZS gave suggestions about project design. All authors read and approved the final manuscript.

\section{Ethics approval and consent to participate}

The entire procedure was carried out in strict accordance with the protocol approved by the Animal Care and Use Committee of Sichuan Agricultural University (Approval ID: S20174221) and all experiments performed according to the regulations and guidelines established by this committee.

Consent for publication

Not applicable.

Competing interests

The authors declare that they have no competing interests.

\section{References}

1. Graham DA: Bovine herpes virus-1 (BoHV-1) in cattle-a review with emphasis on reproductive impacts and the emergence of infection in Ireland and the United Kingdom. Irish veterinary journal 2013, 66(1):15.

2. Mahajan V, Banga HS, Deka D, Filia G, Gupta A: Comparison of diagnostic tests for diagnosis of infectious bovine rhinotracheitis in natural cases of bovine abortion. Journal of comparative pathology 2013, 149(4):391-401.

3. Donofrio G, Herath S, Sartori C, Cavirani S, Flammini CF, Sheldon IM: Bovine herpesvirus 4 is tropic for bovine endometrial cells and modulates endocrine function. Reproduction 2007, 134(1):183.

4. Vermillion MS, Lei J, Shabi Y, Baxter VK, Crilly NP, McLane M, Griffin DE, Pekosz A, Klein SL, Burd I: Intrauterine Zika virus infection of pregnant immunocompetent mice models transplacental transmission and adverse perinatal outcomes. Nature Communications, 8:14575.

5. Yang C, Hao X, Li Y, Long F, He Q, Huang F, Yu W: Successful Establishment of Hepatitis E Virus Infection in Pregnant BALB/c Mice. Viruses 2019, 11(5). 
6. Xia J, Liu L, Wang L, Zhang Y, Zeng H, Liu P, Zou Q, Wang L, Zhuang H: Experimental infection of pregnant rabbits with hepatitis $\mathrm{E}$ virus demonstrating high mortality and vertical transmission. Journal of viral hepatitis 2015, 22(10):850-857.

7. Lanyon SR, Hill Fl, Reichel MP, Brownlie J: Bovine viral diarrhoea: pathogenesis and diagnosis. Veterinary journal 2014, 199(2):201-209.

8. Sheldon IM, Cronin J, Goetze L, Donofrio G, Schuberth HJ: Defining postpartum uterine disease and the mechanisms of infection and immunity in the female reproductive tract in cattle. Biology of reproduction 2009, 81(6):1025-1032.

9. Ponting CP, Oliver PL, Reik W: Evolution and functions of long noncoding RNAs. Cel/ 2009, 136(4):629-641.

10. Wang KC, Chang HY: Molecular mechanisms of long noncoding RNAs. Molecular cel/ 2011, 43(6):904-914.

11. Zeng N, Wang C, Liu S, Miao Q, Zhou L, Ge X, Han J, Guo X, Yang H: Transcriptome Analysis Reveals Dynamic Gene Expression Profiles in Porcine Alveolar Macrophages in Response to the Chinese Highly Pathogenic Porcine Reproductive and Respiratory Syndrome Virus. BioMed research international 2018, 2018:1538127.

12. Fatica A, Bozzoni I: Long non-coding RNAs: new players in cell differentiation and development. Nature reviews Genetics 2014, 15(1):7-21.

13. Heward JA, Lindsay MA: Long non-coding RNAs in the regulation of the immune response. Trends in immunology 2014, 35(9):408-419.

14. Zacharopoulou E, Gazouli M, Tzouvala M, Vezakis A, Karamanolis G: The contribution of long noncoding RNAs in Inflammatory Bowel Diseases. Digestive and liver disease : official journal of the Italian Society of Gastroenterology and the Italian Association for the Study of the Liver 2017, 49(10):1067-1072.

15. Nishitsuji H, Ujino S, Yoshio S, Sugiyama M, Mizokami M, Kanto T, Shimotohno K: Long noncoding RNA \#32 contributes to antiviral responses by controlling interferon-stimulated gene expression. Proceedings of the National Academy of Sciences of the United States of America 2016, 113(37):10388-10393.

16. Ouyang J, Zhu X, Chen Y, Wei H, Chen Q, Chi X, Qi B, Zhang L, Zhao Y, Gao GF et al: NRAV, a long noncoding RNA, modulates antiviral responses through suppression of interferon-stimulated gene transcription. Cell host \& microbe 2014, 16(5):616-626.

17. Wang $P, X u J$, Wang $Y$, Cao X: An interferon-independent IncRNA promotes viral replication by modulating cellular metabolism. Science 2017, 358(6366):1051-1055.

18. Eddleston J, Lee RU, Doerner AM, Herschbach J, Zuraw BL: Cigarette smoke decreases innate responses of epithelial cells to rhinovirus infection. American journal of respiratory cell and molecular biology 2011, 44(1):118-126.

19. Yu M, Levine SJ: Toll-like receptor, RIG-Ilike receptors and the NLRP3 inflammasome: key modulators of innate immune responses to double-stranded RNA viruses. Cytokine \& growth factor reviews 2011, 
22(2):63-72.

20. Jiang R, Ye J, Zhu B, Song Y, Chen H, Cao S: Roles of TLR3 and RIG-I in mediating the inflammatory response in mouse microglia following Japanese encephalitis virus infection. Journal of immunology research 2014, 2014:787023.

21. Kleinman ME, Kaneko H, Cho WG, Dridi S, Fowler BJ, Blandford AD, Albuquerque RJ, Hirano Y, Terasaki $\mathrm{H}$, Kondo $\mathrm{M}$ et al: Short-interfering RNAs induce retinal degeneration via TLR3 and IRF3. Molecular therapy : the journal of the American Society of Gene Therapy 2012, 20(1):101-108.

22. Liang Z, Wu S, Li Y, He L, Wu M, Jiang L, Feng L, Zhang P, Huang X: Activation of Toll-like receptor 3 impairs the dengue virus serotype 2 replication through induction of IFN-beta in cultured hepatoma cells. PloS one 2011, 6(8):e23346.

23. Alexopoulou L, Holt AC, Medzhitov R, Flavell RA: Recognition of double-stranded RNA and activation of NF-kappaB by Toll-like receptor 3. Nature 2001, 413(6857):732-738.

24. Negishi H, Osawa T, Ogami K, Ouyang X, Sakaguchi S, Koshiba R, Yanai H, Seko Y, Shitara H, Bishop $\mathrm{K}$ et al: A critical link between Toll-like receptor 3 and type II interferon signaling pathways in antiviral innate immunity. Proceedings of the National Academy of Sciences of the United States of America 2008, 105(51):20446-20451.

25. Desmet CJ, Ishii KJ: Nucleic acid sensing at the interface between innate and adaptive immunity in vaccination. Nature reviews Immunology 2012, 12(7):479-491.

26. Karpus ON, Heutinck KM, Wijnker PJ, Tak PP, Hamann J: Triggering of the dsRNA sensors TLR3, MDA5, and RIG-I induces CD55 expression in synovial fibroblasts. PloS one 2012, 7(5):e35606.

27. Chang ST, Sova P, Peng X, Weiss J, Law GL, Palermo RE, Katze MG: Next-generation sequencing reveals HIV-1-mediated suppression of T cell activation and RNA processing and regulation of noncoding RNA expression in a CD4+ T cell line. mBio 2011, 2(5).

28. Moran VA, Perera RJ, Khalil AM: Emerging functional and mechanistic paradigms of mammalian long non-coding RNAs. Nucleic acids research 2012, 40(14):6391-6400.

29. Wang Z, Gerstein M, Snyder M: RNA-Seq: a revolutionary tool for transcriptomics. Nature reviews Genetics 2009, 10(1):57-63.

30. Metzler MA, Sandell LL: Enzymatic Metabolism of Vitamin A in Developing Vertebrate Embryos. Nutrients 2016, 8(12).

31. Goteri G, Altobelli E, Tossetta G, Zizzi A, Avellini C, Licini C, Lorenzi T, Castellucci M, Ciavattini A, Marzioni D: High temperature requirement A1, transforming growth factor beta1, phosphoSmad2 and Ki67 in eutopic and ectopic endometrium of women with endometriosis. European journal of histochemistry : EJH2015, 59(4):2570.

32. Belli M, Shimasaki S: Molecular Aspects and Clinical Relevance of GDF9 and BMP15 in Ovarian Function. Vitamins and hormones 2018, 107:317-348.

33. Zheng J, Wang Z, Yang H, Yao X, Yang P, Ren C, Wang F, Zhang Y: Pituitary Transcriptomic Study Reveals the Differential Regulation of IncRNAs and mRNAs Related to Prolificacy in Different FecB Genotyping Sheep. Genes 2019, 10(2). 
34. Bu Q, Hu Z, Chen F, Zhu R, Deng Y, Shao X, Li Y, Zhao J, Li H, Zhang B et al: Transcriptome analysis of long non-coding RNAs of the nucleus accumbens in cocaine-conditioned mice. Journal of neurochemistry 2012, 123(5):790-799.

35. Han L, Zhang K, Shi Z, Zhang J, Zhu J, Zhu S, Zhang A, Jia Z, Wang G, Yu S et al: LncRNA pro fi le of glioblastoma reveals the potential role of IncRNAs in contributing to glioblastoma pathogenesis. International journal of oncology 2012, 40(6):2004-2012.

36. Cai B, Li Z, Ma M, Wang Z, Han P, Abdalla BA, Nie Q, Zhang X: LncRNA-Six1 Encodes a Micropeptide to Activate Six1 in Cis and Is Involved in Cell Proliferation and Muscle Growth. Frontiers in physiology 2017, 8:230.

37. Yang L, Yi K, Wang H, Zhao Y, Xi M: Comprehensive analysis of IncRNAs microarray profile and mRNA-IncRNA co-expression in oncogenic HPV-positive cervical cancer cell lines. Oncotarget 2016, 7(31):49917-49929.

38. Wang XJ, Jiang SC, Wei HX, Deng SQ, He C, Peng HJ: The Differential Expression and Possible Function of Long Noncoding RNAs in Liver Cells Infected by Dengue Virus. The American journal of tropical medicine and hygiene 2017, 97(6):1904-1912.

39. Niringiyumukiza JD, Cai H, Xiang W: Prostaglandin E2 involvement in mammalian female fertility: ovulation, fertilization, embryo development and early implantation. Reproductive biology and endocrinology : RB\&E 2018, 16(1):43.

40. Wang H, Dey SK: Lipid signaling in embryo implantation. Prostaglandins \& other lipid mediators 2005, 77(1-4):84-102.

41. Thirukkumaran C, Shi ZQ, Thirukkumaran P, Luider J, Kopciuk K, Spurrell J, Elzinga K, Morris D: PUMA and NF-kB Are Cell Signaling Predictors of Reovirus Oncolysis of Breast Cancer. PloS one 2017, 12(1):e0168233.

42. Reinert LS, Harder L, Holm CK, Iversen MB, Horan KA, Dagnaes-Hansen F, Ulhoi BP, Holm TH, Mogensen TH, Owens T et al: TLR3 deficiency renders astrocytes permissive to herpes simplex virus infection and facilitates establishment of CNS infection in mice. The Journal of clinical investigation 2012, 122(4):1368-1376.

43. Sinkora M, Butler JE: The ontogeny of the porcine immune system. Developmental and comparative immunology 2009, 33(3):273-283.

44. Fischer C, Drillich M, Odau S, Heuwieser W, Einspanier R, Gabler C: Selected pro-inflammatory factor transcripts in bovine endometrial epithelial cells are regulated during the oestrous cycle and elevated in case of subclinical or clinical endometritis. Reproduction, fertility, and development 2010, 22(5):818-829.

45. Gabler C, Fischer C, Drillich M, Einspanier R, Heuwieser W: Time-dependent mRNA expression of selected pro-inflammatory factors in the endometrium of primiparous cows postpartum. Reproductive biology and endocrinology : RB\&E 2010, 8:152.

46. Zerbe H, Ossadnik C, Leibold W, Schuberth HJ: Lochial secretions of Escherichia coli- or Arcanobacterium pyogenes-infected bovine uteri modulate the phenotype and the functional 
capacity of neutrophilic granulocytes. Theriogenology 2002, 57(3):1161-1177.

47. Medzhitov R: Origin and physiological roles of inflammation. Nature 2008, 454(7203):428-435.

48. Yoshimura $A$, Mori $H$, Ohishi M, Aki D, Hanada $T$ : Negative regulation of cytokine signaling influences inflammation. Current opinion in immunology 2003, 15(6):704-708.

49. Loyi T, Kumar H, Nandi S, Mathapati BS, Patra MK, Pattnaik B: Differential expression of proinflammatory cytokines in endometrial tissue of buffaloes with clinical and sub-clinical endometritis. Research in veterinary science 2013, 94(2):336-340.

50. Galvao KN, Santos NR, Galvao JS, Gilbert RO: Association between endometritis and endometrial cytokine expression in postpartum Holstein cows. Theriogenology 2011, 76(2):290-299.

51. Herath S, Lilly ST, Santos NR, Gilbert RO, Goetze L, Bryant CE, White JO, Cronin J, Sheldon IM: Expression of genes associated with immunity in the endometrium of cattle with disparate postpartum uterine disease and fertility. Reproductive biology and endocrinology : RB\&E 2009, 7:55.

52. Djebali S, Davis CA, Merkel A, Dobin A, Lassmann T, Mortazavi A, Tanzer A, Lagarde J, Lin W, Schlesinger $F$ et al: Landscape of transcription in human cells. Nature 2012, 489(7414):101-108.

53. Khalil AM, Guttman M, Huarte M, Garber M, Raj A, Rivea Morales D, Thomas K, Presser A, Bernstein $\mathrm{BE}$, van Oudenaarden $\mathrm{A}$ et al: Many human large intergenic noncoding RNAs associate with chromatin-modifying complexes and affect gene expression. Proceedings of the National Academy of Sciences of the United States of America 2009, 106(28):11667-11672.

54. Randall RE, Goodbourn S: Interferons and viruses: an interplay between induction, signalling, antiviral responses and virus countermeasures. The Journal of general virology 2008, 89(Pt 1):1-47.

55. Samuel CE: Antiviral actions of interferons. Clinical microbiology reviews 2001, 14(4):778-809, table of contents.

56. Sadler AJ, Williams BR: Interferon-inducible antiviral effectors. Nature reviews Immunology 2008, 8(7):559-568.

57. Zhao C, Denison C, Huibregtse JM, Gygi S, Krug RM: Human ISG15 conjugation targets both IFNinduced and constitutively expressed proteins functioning in diverse cellular pathways. Proceedings of the National Academy of Sciences of the United States of America 2005, 102(29):10200-10205.

58. Silverman RH: Viral encounters with 2',5'-oligoadenylate synthetase and RNase $L$ during the interferon antiviral response. Journal of virology 2007, 81(23):12720-12729.

59. Weber F, Haller O, Kochs G: MxA GTPase blocks reporter gene expression of reconstituted Thogoto virus ribonucleoprotein complexes. Journal of virology 2000, 74(1):560-563.

60. Fortes P, Morris KV: Long noncoding RNAs in viral infections. Virus research 2016, 212:1-11.

61. Liu W, Ding C: Roles of LncRNAs in Viral Infections. Frontiers in cellular and infection microbiology 2017, 7:205.

62. Pertea M, Kim D, Pertea GM, Leek JT, Salzberg SL: Transcript-level expression analysis of RNA-seq experiments with HISAT, StringTie and Ballgown. Nature protocols 2016, 11(9):1650-1667. 


\section{Figures}

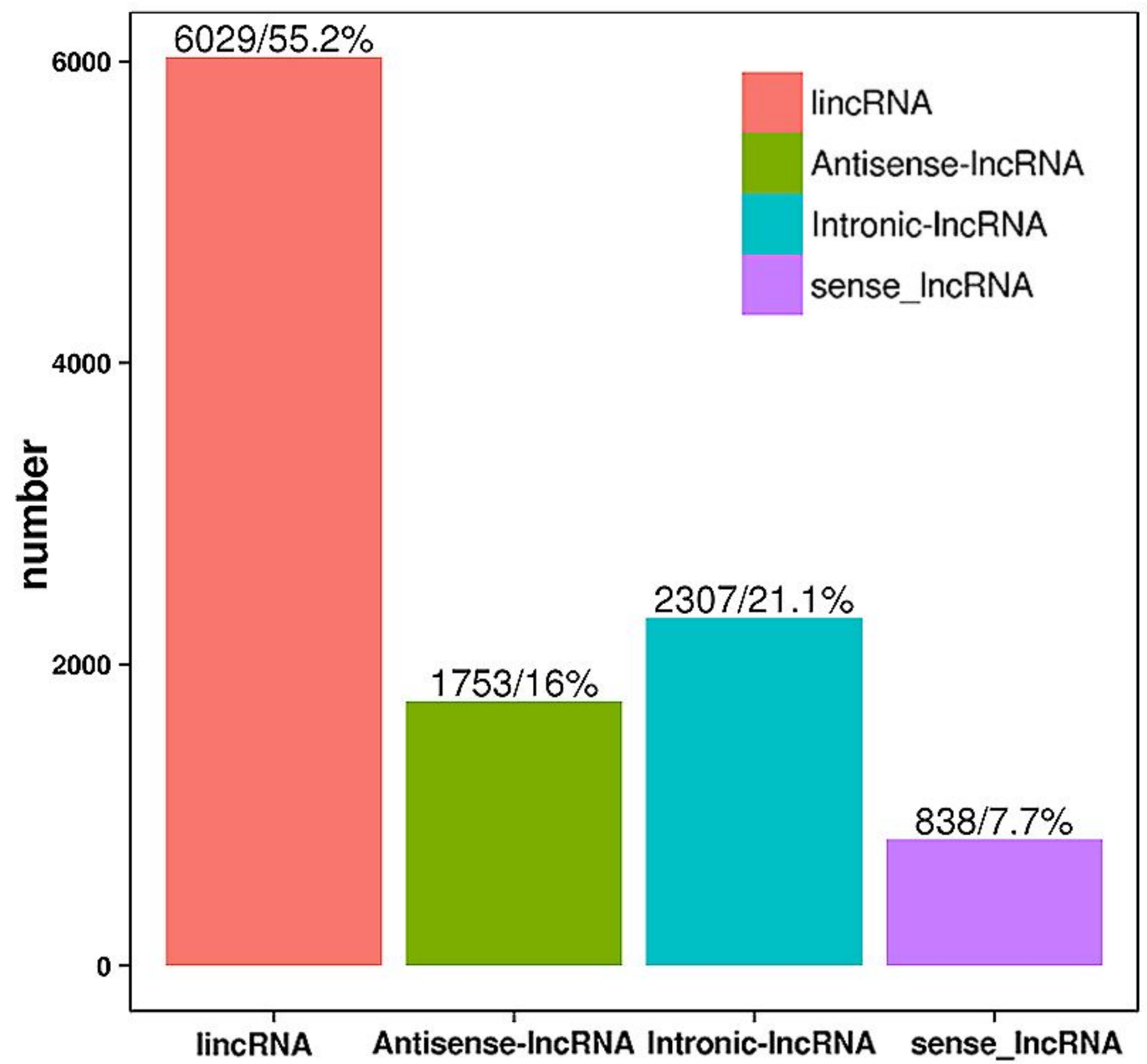

Figure 1

LncRNA classification of ESCs. The identified IncRNAs were divided into four types: intergenic IncRNA, antisense IncRNA, sense IncRNA and intronic IncRNA. 

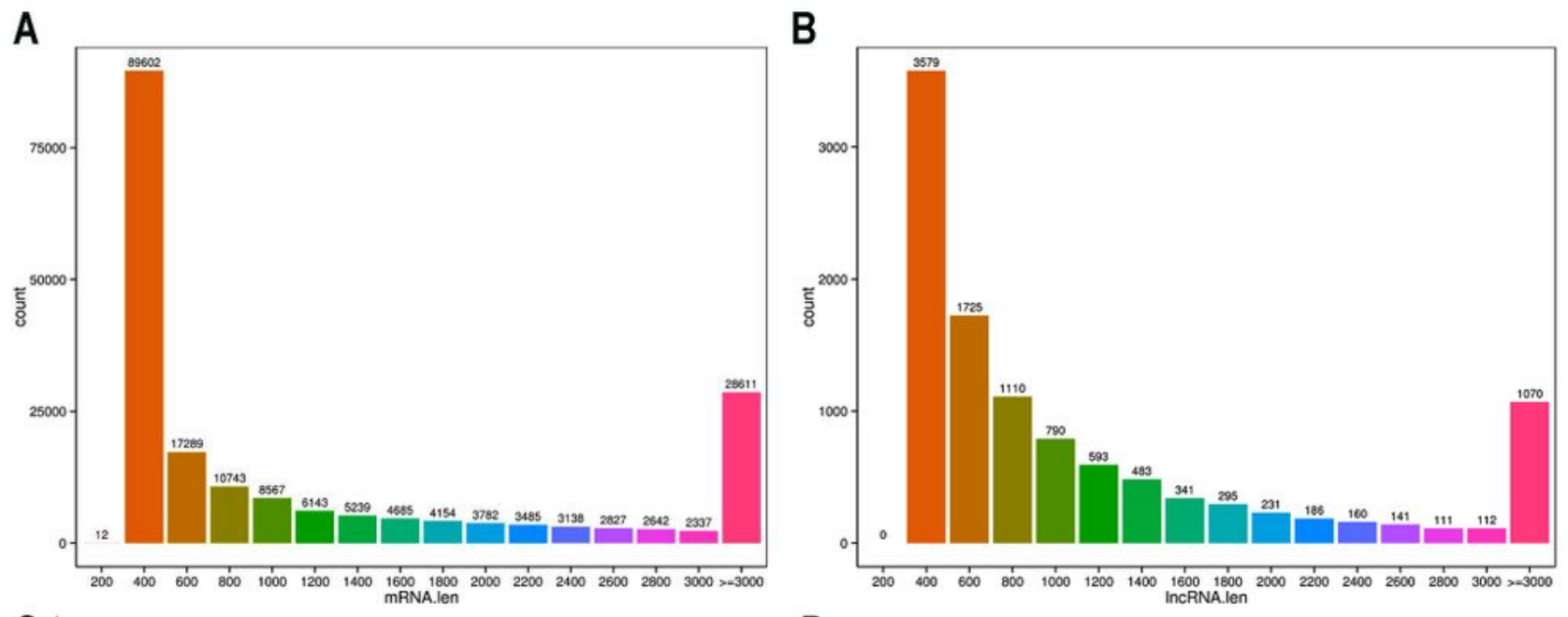

C

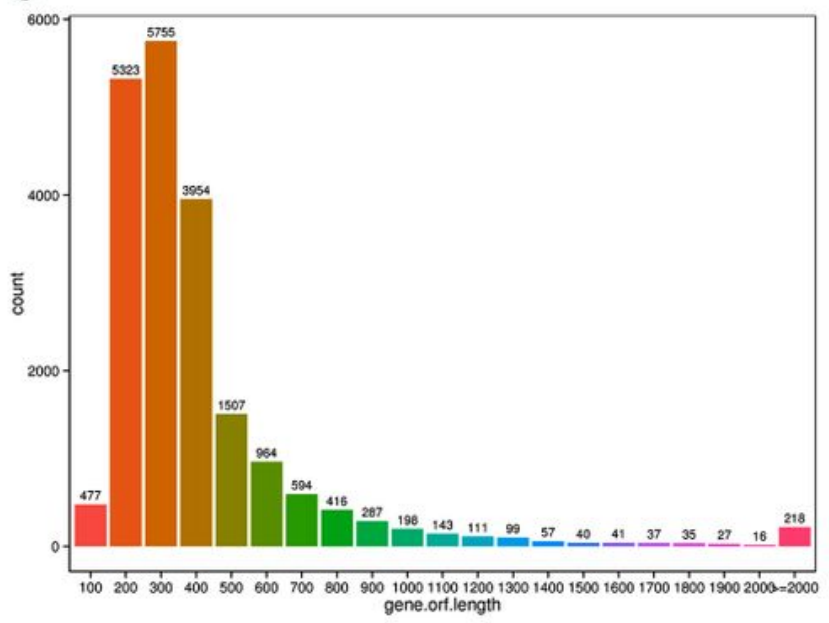

D

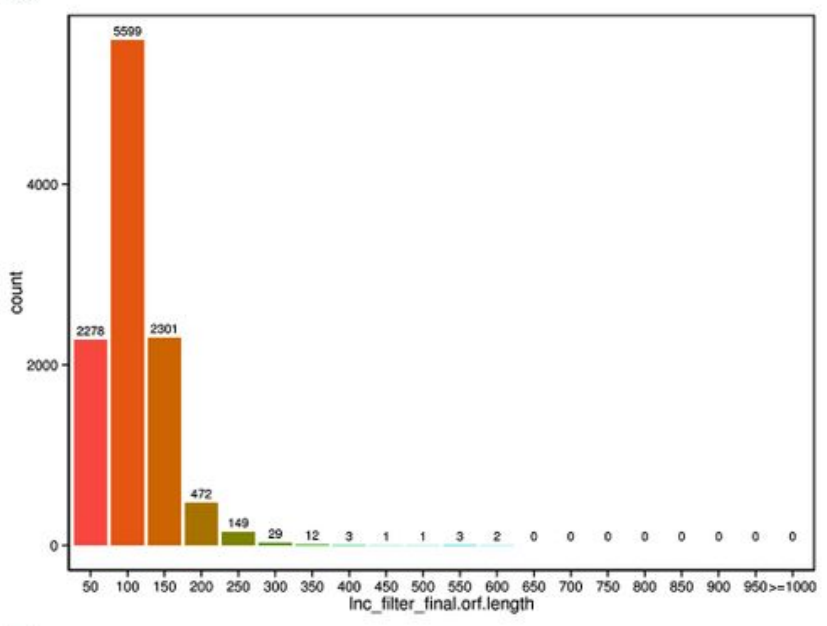

E

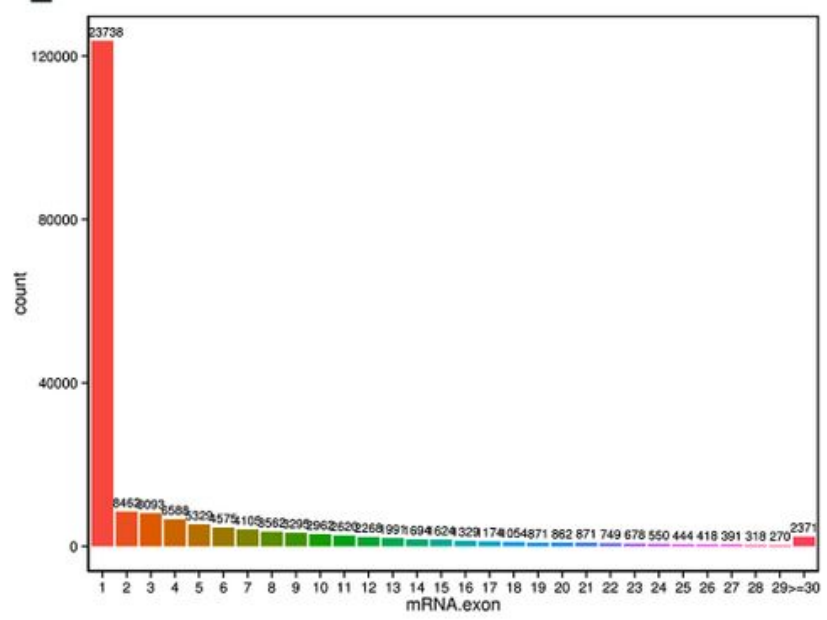

$\mathbf{F}$

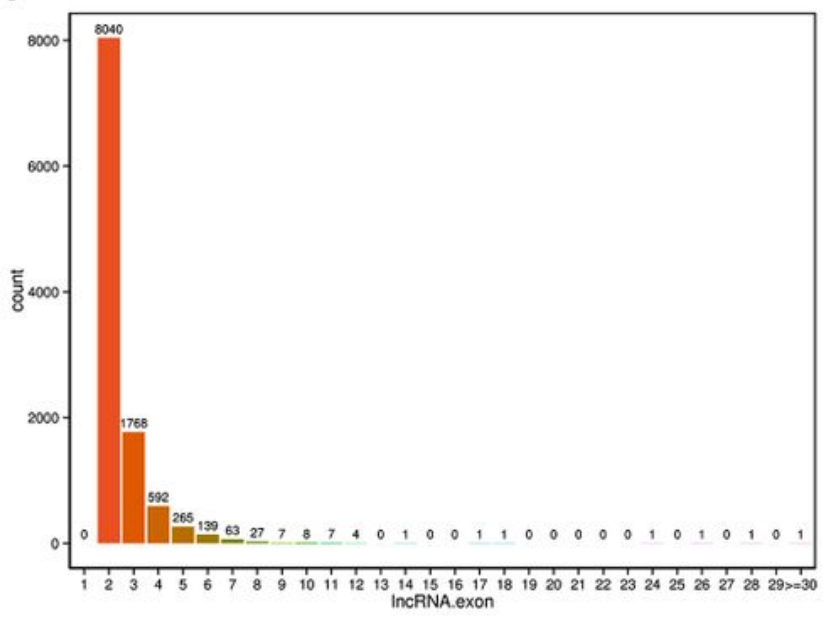

Figure 2

characterization of IncRNA and mRNA. (A) Length statistics of IncRNA and mRNA. The abscissa is the length, and the ordinate is the number of IncRNAs and mRNAs whose length is distributed within this range. (B) Statistics on the ORF length of IncRNAs and mRNAs. The abscissa is the ORF length and the ordinate is the number of IncRNAs and mRNAs. (C) Exon number of IncRNA and mRNA. The abscissa is the number of exons, and the ordinate is the number of corresponding IncRNAs and mRNAs. 

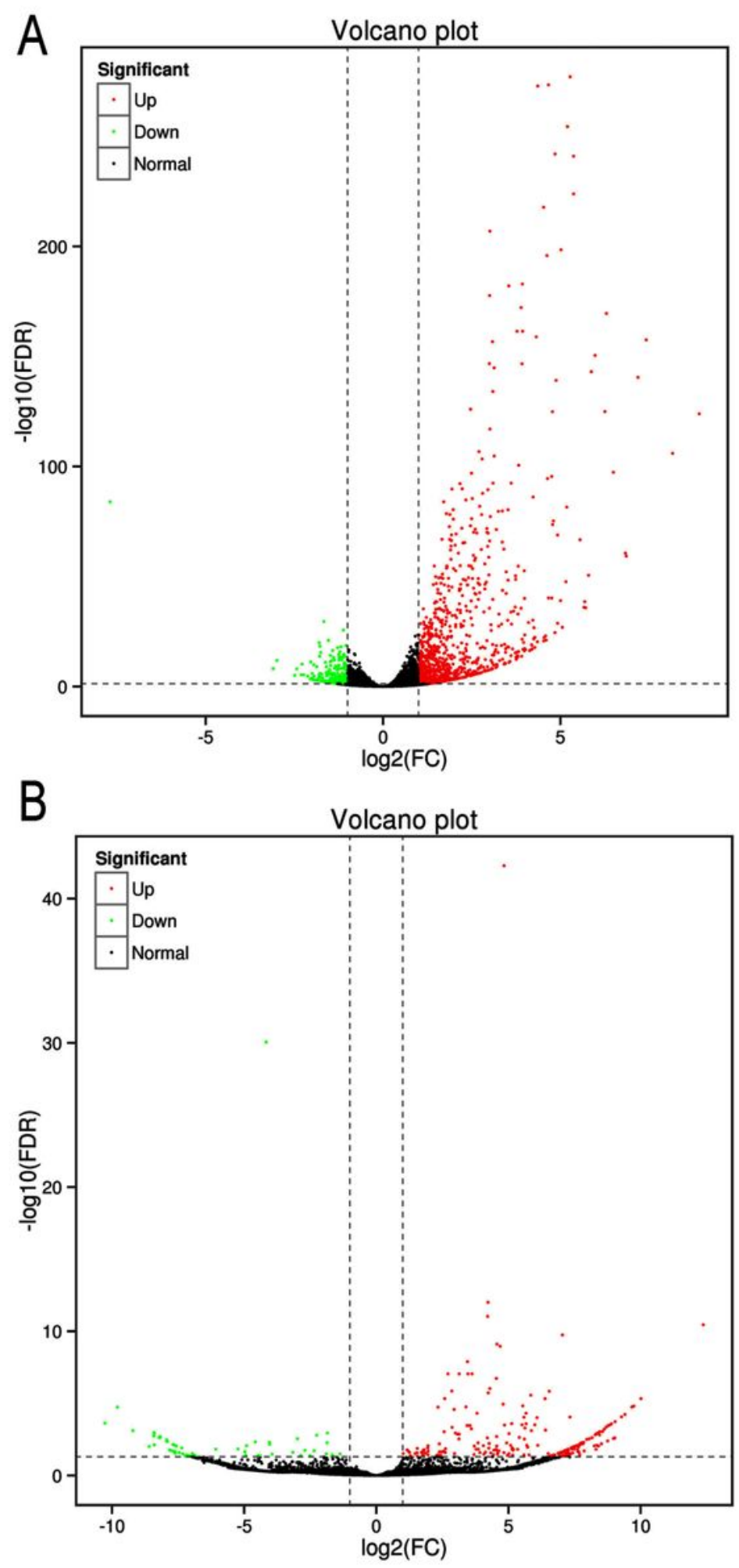

\section{Figure 3}

Analysis of differentially expressed mRNAs and IncRNAs. (A) The volcano plot of DE mRNAs. (B) The volcano plot of DE IncRNA. Green dots represent down-regulated mRNA or IncRNA, red dots represent upregulated mRNA or IncRNA, and black dots represent non-differentiated mRNA or IncRNA. 


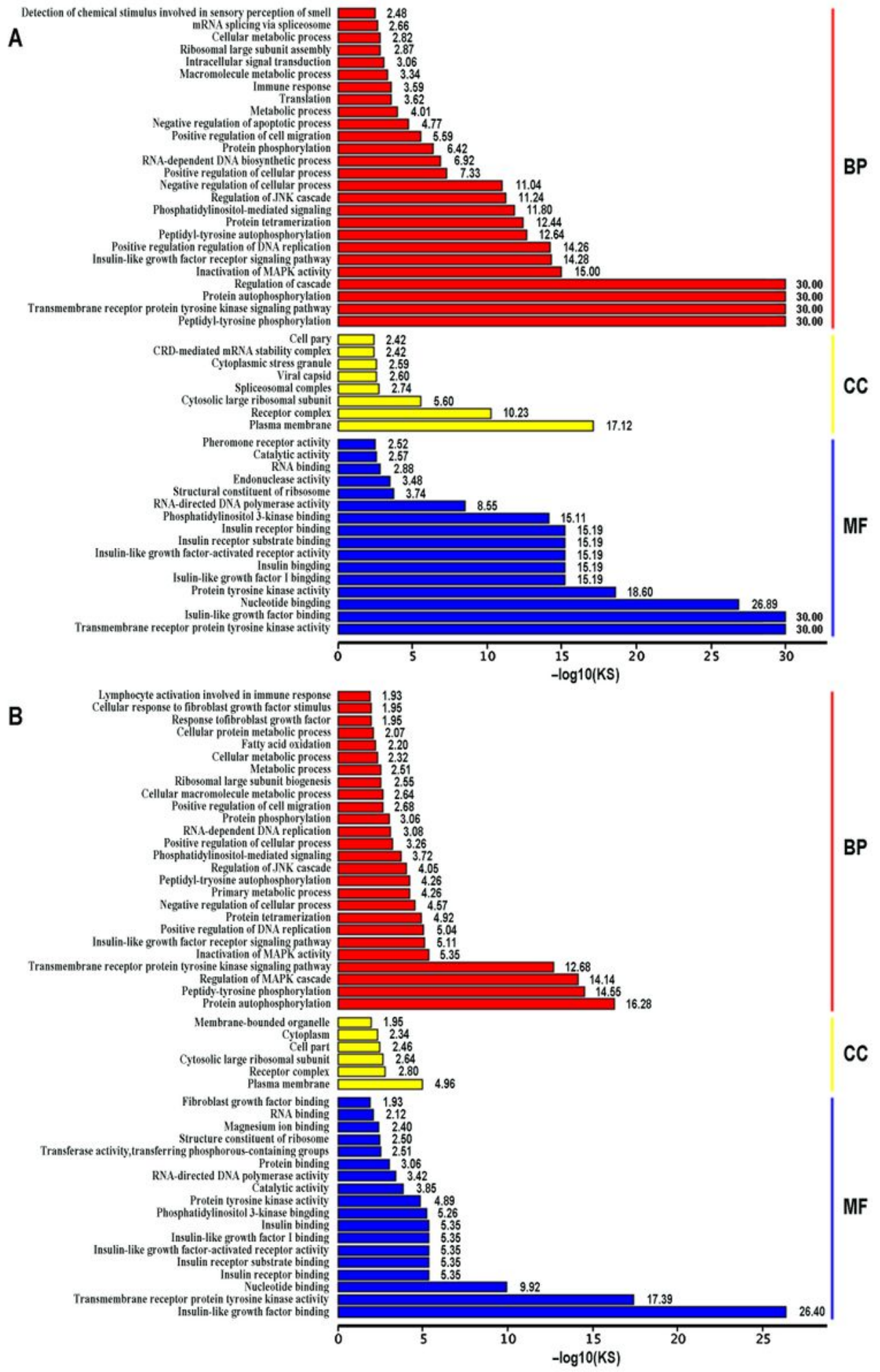

\section{Figure 4}

GO analysis. (A) GO analysis of DE mRNAs. (B) GO analysis of target genes of DE-IncRNAs. Abscissa, Enrichment score; ordinate, GO terms. BP, biological process; CC, cellular component; MF, molecular function. 


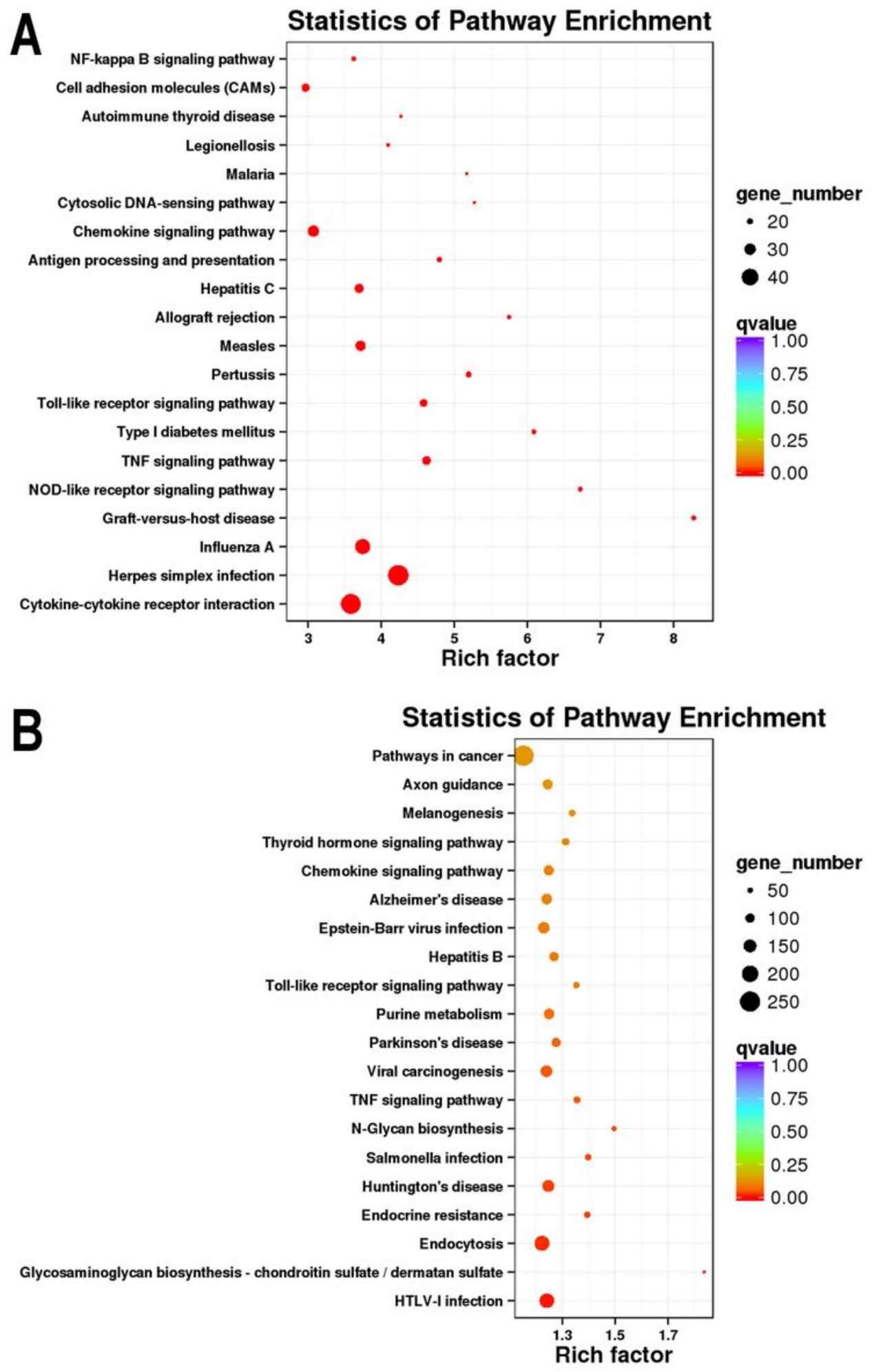

\section{Figure 5}

KEGG enrichment analysis. Scatter plot of the top 20 KEGG pathways enriched for DE mRNAs (A) and target genes of DE IncRNAs (B) in ESCs. The abscissa is the enrichment factor and the ordinate is the enrichment pathway. Each circle represents a KEGG pathway, the color of the circle represents the q value (corrected $p$ value), and the size represents the number of genes enriched in the pathway. 


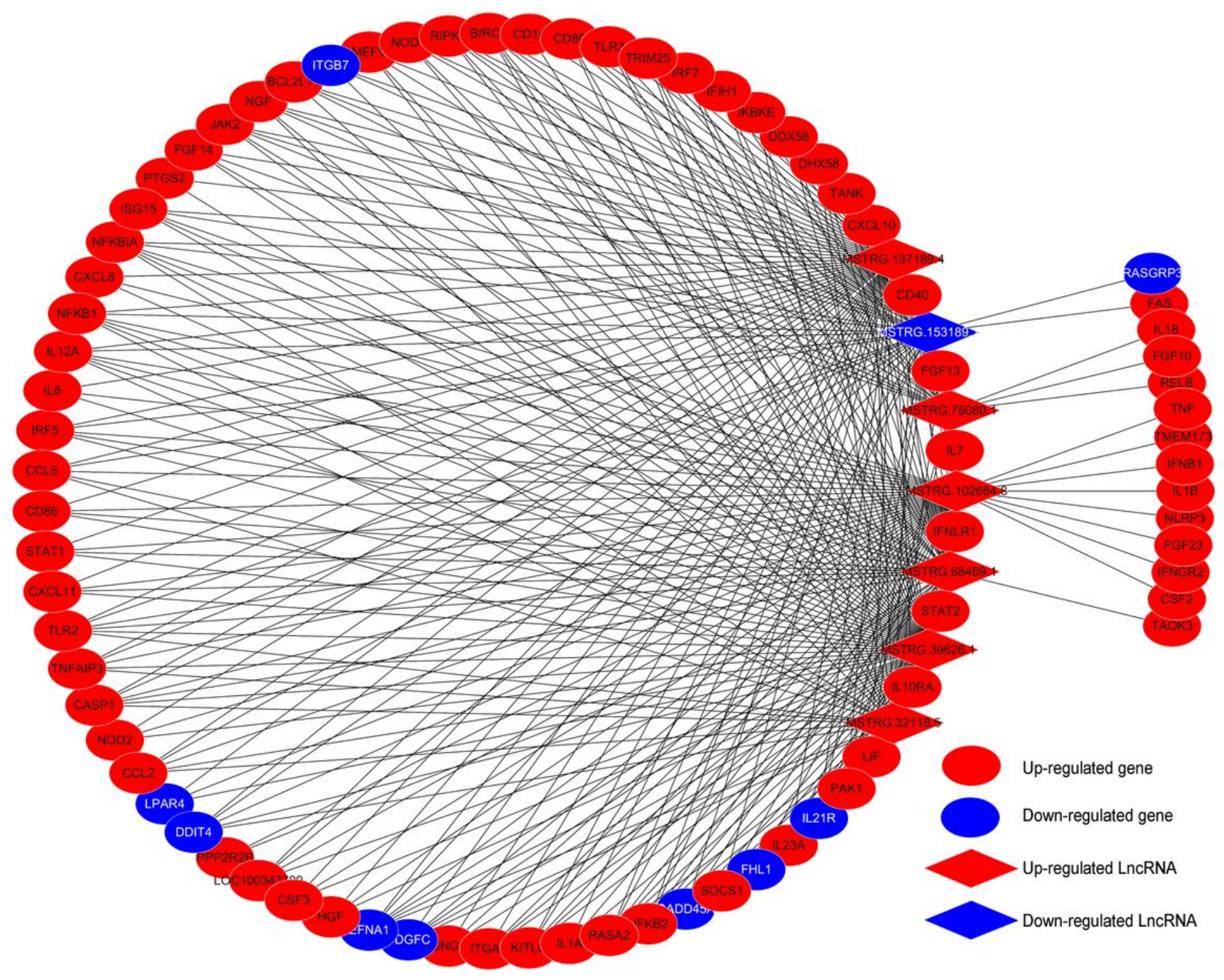

Figure 6

Interaction network of seven IncRNAs and their 78 targeted genes enriched in immune response pathways. 
A

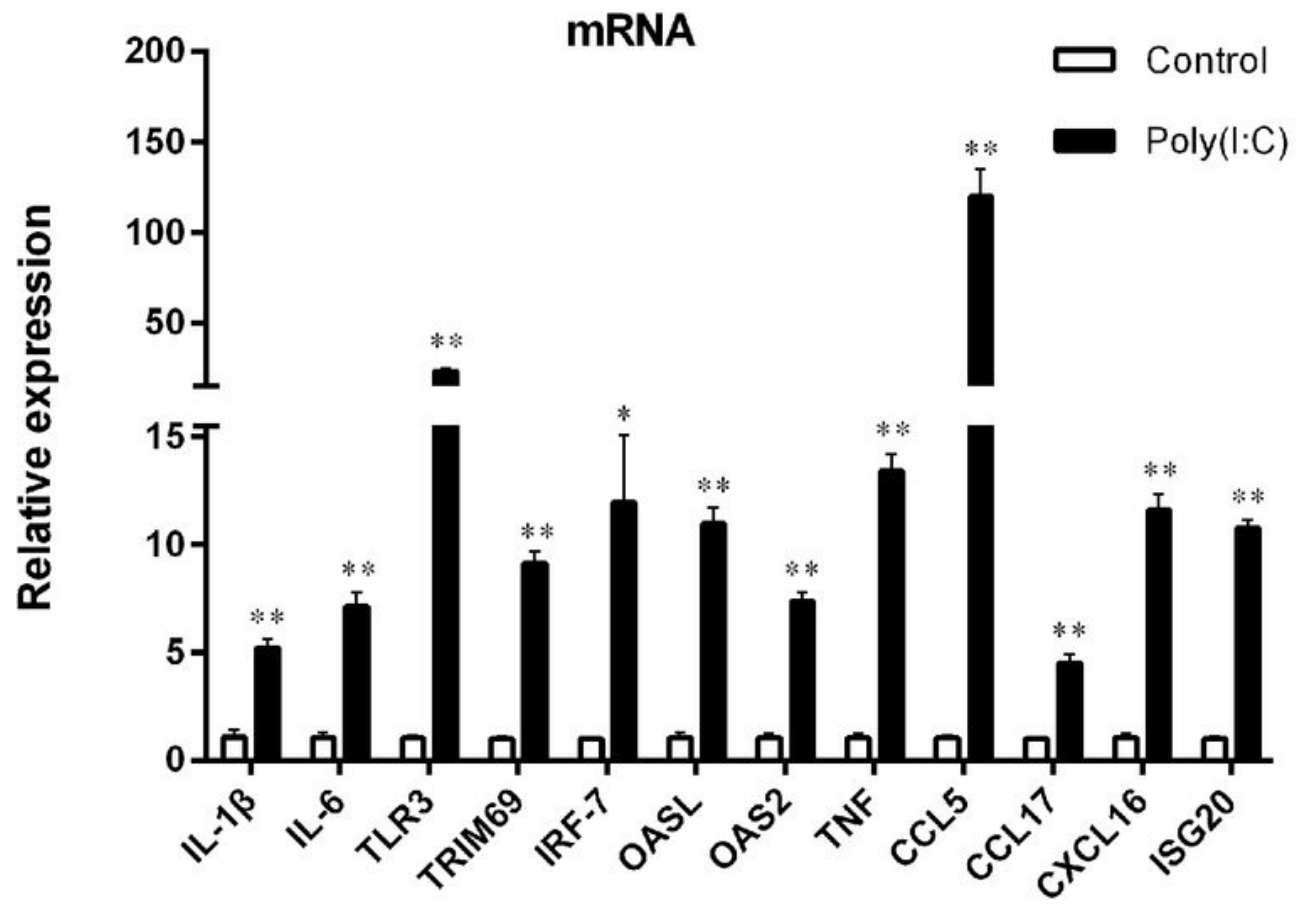

B

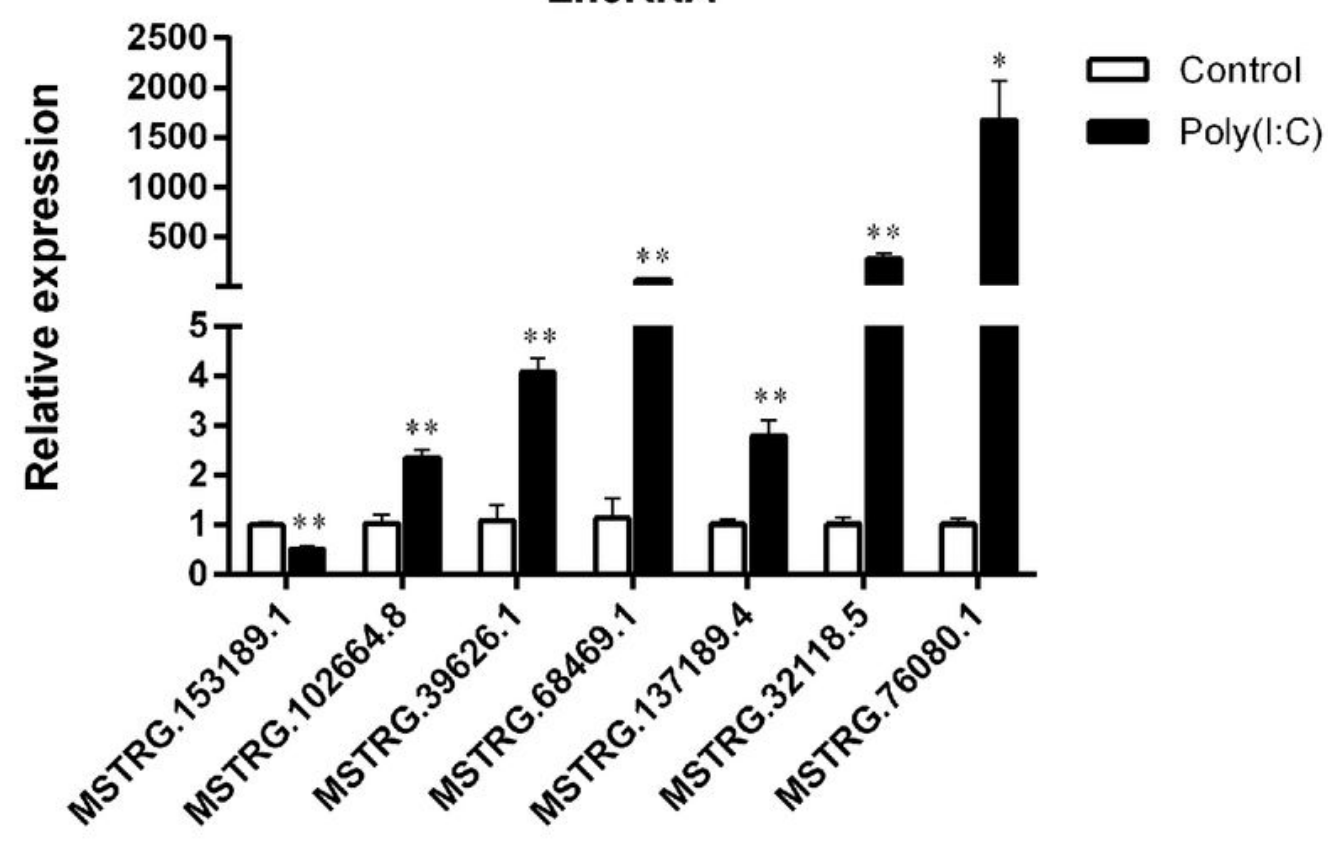

Figure 7

Validation of differentially expressed mRNAs and IncRNAs by RT-qPCR. (A) RT-qPCR validation of mRNA expression changes between control group and poly(l:C) group. (B) RT-qPCR validation of IncRNA expression changes between control group and poly(l:C) group. RT-qPCR data were calculated by the 2- $\Delta \Delta \mathrm{Ct}$ method with GAPDH as internal control. ${ }^{\star} p<0.05,{ }^{\star *} p<0.01$. 


\section{Supplementary Files}

This is a list of supplementary files associated with this preprint. Click to download.

- TableS6.KEGGenrichment.xIsx

- TableS7TargetgenesofDElncRNAs.xlsx

- TableS3.DEmRNAs.xlsx

- TableS2.SequenceoftotallncRNAs.xlsx

- TableS5.GOofmRNA.xlsx

- TableS8.GOofDElncRNAs.xlsx

- FigureS1.jpg

- TableS9KEGGofDElncRNAs.xIsx

- TableS4.DEIncRNAs.xIsx 